\title{
POTENTIAL GROWTH INHIBITION ACTIVITY OF FECAL MATERIALS, MUCUS AND CULTURED WATER OF TILAPIA OREOCHROMIS NILOTICUS ON ACUTE HEPATOPANCREATIC NECROSIS DISEASE (AHPND) - CAUSING PATHOGEN VIBRIO PARAHAEMOLYTICUS
}

\author{
Le Ngoc Phuong Thanh, Ho Hai Co, Trinh Thi Truc Ly, Hoang Tung, Bui Thi Hong Hanh ${ }^{\bowtie}$ \\ International University, Vietnam National University Ho Chi Minh City \\ ${ }^{凶}$ To whom correspondence should be addressed. E-mail: bthhanh@hcmiu.edu.vn
}

Received: 03.10.2017

Accepted: 28.12.2017

SUMMARY

Shrimp farming plays a key role in economy of many countries all over the world. Unfortunately, a disease called Acute Hepatopancreatic Necrosis Disease (AHPND) or Early Mortality Syndrome (EMS) caused by Vibrio parahaemolyticus spreading from Asia to Central America costs shrimp industry billions of dollars annually. In the past few years, scientists from multi-disciplinary field collaborated to find out a solution for this disease. Until now, there are not any effective approaches to prevent and cure this disease. However, coculturing shrimp with tilapia was carried out to limit the outbreak of AHPND in farm scale in many countries. Some previous studies also mentioned the benefits of this farming method to prevent other pathogens. The aim of this research is to determine whether intrinsic factors or cultured water of tilapia play role in inhibition of $V$. parahaemolyticus - pathogen causing AHPND. These factors include: mucus on tilapia gill and skin, tilapia fecal material, and microbiota or dissolved chemicals in culturing of tilapia. Anti- $V$. parahaemolyticus activity of tilapia (Oreochromis niloticus) fresh and overnight incubated feces and mucus were tested using agar well diffusion method. The effectiveness of feces and mucus inhibition was not clear, both of samples generated a weak inhibition on $V$. parahaemolyticus. Determination of $V$. parahaemolyticus inhibiting factor of tilapia cultured water using challenge test showed that dissolved compounds (smaller than $0.22 \mu \mathrm{m}$ ) inhibited the growth of $V$. parahaemolyticus. The presence of these compounds in tilapia-cultured water reduced $V$. parahaemolyticus to 17 times lower than that of the negative control with the seawater alone within the first three hours post challenge.

Keywords: $A H P N D$, EMS, mucus on tilapia gill and skin, shrimp, tilapia feces, tilapia water, $V$. parahaemolyticus

\section{INTRODUCTION}

Shrimp is one of the high-value commodities and Pacific white shrimp (Panaeus vannamei) is the main species cultured in most of the coastal countries in Asia such as Thailand, China, Vietnam, Malaysia, Philippines. Over the past five years, the world shrimp industry has suffered devastating losses due to acute hepatopancreatic necrosis disease (AHPND), which was also known as early mortality syndrome (EMS). AHPND caused a loss of 5.8 percent (to 3.25 million metric tons (MMT)) in 2012 and 1.1 percent (to $3.21 \mathrm{MMT}$ ) in 2013 to the world shrimp production (Anderson et al., 2016). The loss was especially severe in the Asian region (FAO,
2013). Recent study indicates that a particular strain of $V$. parahaemolyticus can causes mass mortality with typical AHPND histopathology including severe atrophy of the shrimp hepatopancreas, massive sloughing of hepatopancreatic epithelial cells into tubule lumens during first 30 days after stocking (Tran et al., 2013). Tubule cell death is caused by the binary toxin Photorhabdus insectrelated (PirAvp/PirBvp) encoded in the AHPND associated plasmid of the bacterial $V$. parahaemolyticus cells (Lee et al., 2015).

Measures to control disease spread have been implemented in a number of shrimp farms, including improvement of farm and shrimp health management 
practices, or the application of probiotics, traditional herbal medicine and molasses. However, the effectiveness of these measures has not been evaluated (FAO, 2013).

Meanwhile, some studies report that tilapiashrimp polyculture increases the shrimp production and profits which is higher than in monoculture (Hernández-Barraza et al., 2012; Yuan et al., 2010). Farming tilapia and shrimp together, also improves cultured water quality, ecological stability and function of shrimp monoculture (Yuan et al., 2010). According to $\mathrm{Yi}$ and Fitzsimmons (2004), tilapia improve the water color stability and reduce the proportion of shrimps infected by AHPND bacteria when using tilapia-shrimp polyculture. Tendencia et $a l$., (2004) noted that the presence of tilapia in the water can directly inhibit the growth of Vibrio harveyi (a species in the same Harveyi clade of $V$. parahaemolyticus). The authors also suggested that fish-associated microflora may present anti-Vibrio activity. It was reported that the gut and feces of tilapia abound with useful fungi e.g., Penicillium and Aspergillus and yeasts, which could work against the proliferation of luminous bacteria $V$. harveyi (Leaño et al., 2005). Similarly, Lio-Po et al., (2005) reported that the ability of the "green water" to prevent the outbreaks of luminous vibriosis in the tiger shrimp grow-out ponds could be attributed to the presence of anti-Vibrio factors in micro-biota in the water, and on the skin mucus of tilapia. In addition, Tran et al., (2014) reported that using tilapia in the reservoirs of shrimp farms prior to stocking shrimp could induce healthy, balanced biota communities in the pond water, which could give beneficial effects to AHPND prevention. Tilapia is known as a biomanipulator, produce substances that can suppress myriad of pathogen, including Vibrios (Cruz et al., 2008). However, the mechanism behind these phenomena remains to be clarified.

Our study aimed to identify potential factors associated with the tilapia itself or the culturing of tilapia, which inhibit the growth of $V$. parahaemolyticus. Particularly, the study investigated the anti-Vibrio activity of fecal materials and mucus isolated from the skin and gills of the tilapia, Oreochromis niloticus. Furthermore, $V$. parahaemolyticus inhibition activity of algae, bacteria and dissolved chemical compounds in tilapia cultured water was also evaluated. The results of this study could be used as a reference for developing a model of using tilapia to control the outbreak of AHPND, reducing the loss caused by this disease to the shrimp farming.

\section{MATERIALS AND METHODS}

\section{Preparation of tilapia feces, mucus and cultured water}

This study was conducted in laboratories of International University (IU). Seawater (approximately $500 \mathrm{~L}$ ) with the salinity of $30 \mathrm{ppt}$ used for experiment was transported from Can Gio beach to Aqualab (IU). Tilapia, which were healthy, not injured, and similar in size (30 g/individual), provided by University of Agriculture and Forestry were used for the experiments.

Seawater was diluted to $15 \mathrm{ppt}$ in $500 \mathrm{~L}(1.5 \mathrm{x}$ $0.5 \times 0.7 \mathrm{~m}$ ) composite tank before stocking of the tilapia at the density of 20 tilapia $/ \mathrm{m}^{3}$ of water. All tilapia were transferred and stocked in cultured tank with aeration system for two weeks before experiment. Commercial fish feed of Uni-president company with $36 \%$ crude protein (pellet diameter between 2 and $2.5 \mathrm{~mm}$ ) was provided for tilapia daily at amount equivalent to $1.5 \%$ of body weight.

The fragment of the fish intestine containing feces, which was the darker part of the intestine, was collected from two fishes, pooled and homogenized to be used as the fecal material for subsequent experiments. Fecal material was then divided into two portions. One portion was used immediately for the agar well diffusion test and the other was incubated at $30^{\circ} \mathrm{C}$ for $24 \mathrm{~h}$ to imitate the possible proliferation of beneficial bacteria at the bottom of pond in the field before being used in the experiment. The former was referred as the fresh fecal material and the later as the enriched fecal material.

Mucus layer on the skin and gill from 2 fishes were scraped slightly by sterile knife, transferred to clean $1.5 \mathrm{ml}$ Eppendorf tubes, and stored on iced until used.

\section{Bacterial strains and media}

$V$. parahaemolyticus was provided by the Research Institute for Aquaculture No. 2 (RIA2) and stored at $80^{\circ} \mathrm{C}$ in tryptone soybean broth (TSB) (HiMedia, India) with $2 \% \mathrm{NaCl}$ with $15 \%$ glycerol. Bacterial strain was cultured in TSB with $2 \% \mathrm{NaCl}$ and maintained on agar plates. Thiosulfate-citrate-bile salts-sucrose (TCBS) 
agar (HiMedia, India) for selecting Vibrio strains was used for well diffusion test.

\section{Confirmation of AHPND related strain by multiplex PCR}

DNA was extracted from the $V$. parahaemolyticus stock that was going to be used in the challenge tests using AccuLite AHPND Detection Kit (EMS) of Khoa Thuong Biotechnology Company. The isolated DNA was then used as template for multiplex PCR to confirm pathogenic strain causing AHPND as instruction from the kit producer.

Seawater used for challenges tests was also checked for the presence of $V$. parahaemolyticus by multiplex PCR.

Agar well diffusion assay to test antibacterial activity of tilapia feces and mucus on $V$. parahaemolyticus

$V$. parahaemolyticus was inoculated in $50 \mathrm{ml}$ TSB with $2 \% \mathrm{NaCl}$, and then incubated at $37^{\circ} \mathrm{C}$ in a rotary shaker agitated at $90 \mathrm{rpm}$ overnight. The density of inoculum was checked by measuring the turbidity of the suspension at OD600. The bacterial suspension was then diluted to $10^{6} \mathrm{CFU} / \mathrm{ml}$ with $0.9 \% \mathrm{NaCl}$ solution. After that, $200 \mu \mathrm{l}$ of diluted bacterial suspension was transferred on to each of TCBS plates and spread using triangle loop until dry completely. On each plate, four wells with diameter of $6 \mathrm{~mm}$ were then made. Fresh or enriched fecal sample or mucus was put into two wells ( $3 \mathrm{~g} /$ well for feces and $2 \mathrm{~g} /$ well for mucus). Other two wells were filled with $50 \mu 1$ distilled water or $50 \mu 1$ of $0.1 \mathrm{mg} / \mathrm{ml}$ doxycycline (STADA, Vietnam) as negative and positive control, respectively. These plates were incubated for $24-48$ hours at $30^{\circ} \mathrm{C}$. The presence of antibacterial zone of inhibition was checked after incubation. The experiment was performed in triplicate.

Challenge tests to identify factor(s) (i.e. algae, bacteria or dissolved compounds) in tilapia cultured water that could inhibit the growth of $V$. parahaemolyticus

This experiment was conducted in $12 \mathrm{PVC}$ cylinders $(\mathrm{d} \times \mathrm{h}=500 \times 90 \mathrm{~mm})$ to simulate the depth of the water column in the actual shrimp ponds. Each cylinder was aerated by aeration system. The cylinders were divided into four groups of three cylinders each. Each group was correspondent to one treatment. In other word, the experiment was set up with four treatments, which was run in triplicate. Each cylinder of NF group contained $2.5 \mathrm{~L}$ tilapia cultured water, which was not filtered before being added into the cylinders. Each cylinder of NA group contained $2.5 \mathrm{~L}$ tilapia cultured water which was filtered with ashless filter paper, Grade 589/3, $2 \mu \mathrm{m}$ (Whatman, German) to remove algae. NAB treatment contained $2.5 \mathrm{~L}$ tilapia cultured water which was filtered with the nylon filter membrane $0.22 \mu \mathrm{m}$ (Finetech, Taiwan) to remove both algae and bacteria from the water. Cylinders of SW group, which served as the negative control contained $2.5 \mathrm{~L}$ seawater, part of which was originally used for culturing of tilapia. Water in the SW group, therefore, shall have similar composition with the water used for the NF group except for the microbial community or dissolved chemical compounds that were created and/or produced by the culture of tilapia. Table 1 indicates differences between the four treatments in term of factors that were potentially involved in $V$. parahaemolyticus inhibiting activity of the tilapia culture water.

Table 1. Source of water and anti - V. parahaemolyticus potential components in four treatments. NF - non - filtered tilapia cultured water; NA - tilapia cultured water removed algae; NAB - tilapia cultured water removed algae and bacteria; SW sea water.

\begin{tabular}{|c|c|c|c|c|}
\hline \multirow{2}{*}{ Treatment } & \multirow{2}{*}{ Source of water } & \multicolumn{3}{|c|}{$\begin{array}{l}\text { Presence (+)/ Absence (-) of potential } V \text {. } \\
\text { parahaemolyticus inhibition components }\end{array}$} \\
\hline & & Algae & Bacteria & $\begin{array}{l}\text { Dissolved chemical } \\
\text { compounds }\end{array}$ \\
\hline NF & Non- filtered tilapia cultured water & + & + & + \\
\hline NA & $\begin{array}{l}\text { Tilapia cultured water which was filtered through } 2 \mu \mathrm{m} \\
\text { filter membrane }\end{array}$ & - & + & + \\
\hline SW & Sea water & - & - & - \\
\hline
\end{tabular}


Bacterial strain was inoculated in $500 \mathrm{ml}$ TSB with $2 \% \mathrm{NaCl}$, and then incubated at $37^{\circ} \mathrm{C}$ in a rotary shaker agitated at $135 \mathrm{rpm}$ for seven hours. After that, bacterial suspension was spread on TCBS agar plates for determination of $V$. parahaemolyticus density. All treatments were challenged with $V$. parahaemolyticus at the final density of $5 \times 10^{5}$ $\mathrm{CFU} / \mathrm{ml}$.

According to unpublished data (Ho, 2016), the changing of $V$. parahaemolyticus concentration occurs within the first 24 hours post challenge. Therefore, sample collection time was scheduled to the following timepoints: $0-3-6-9-12-18-$ 24-hour post challenge. At each time point, five milliliters of water sample were collected from each cylinder.

Concentration of $V$. parahaemolyticus of each sample was then determined by plate-counting method using the TCBS agar plates. Samples were diluted with $0.9 \% \mathrm{NaCl}$ in a 10 -fold serial dilution; $100 \mu 1$ of diluted cell suspension was then spread on TCBS agar plate by a triangle loop. The plates were incubated at $37^{\circ} \mathrm{C}$ for $24 \mathrm{~h}$. Bluish green colonies that appeared on the plates were then counted.

\section{RESULTS}

\section{Confirmation of AHPND causing $V$. parahaemolyticus strain by multiplex PCR}

The $V$. parahaemolyticus stock provided by RIA2 was confirmed to be the AHPND causing strain by multiplex PCR (Fig. 1). In the other hand, tilapia cultured water was confirmed to be free of AHPND causing $V$. parahaemolyticus strain. So, both tilapia cultured water and the bacteria were appropriate to be used in the challenge tests.

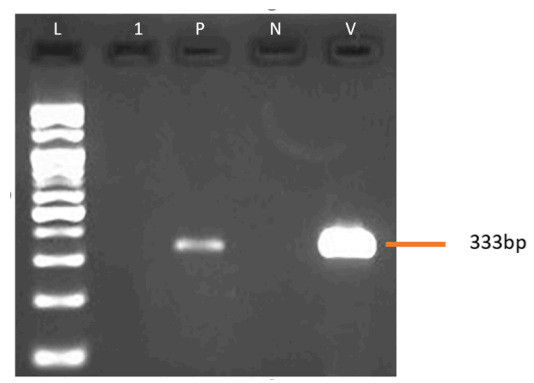

Figure 1. Confirmation of $\mathrm{VP}_{\text {AHPND }}$ strain by multiplex $\mathrm{PCR}$. Lane $\mathrm{L}$ - ladder; Lane 1- Tilapia cultured water; Lane $\mathrm{P}$ - Positive control (333 bp); Lane N - Negative control; Lane V - AHPND - causing V. parahaemolyticus used in the challenge test.
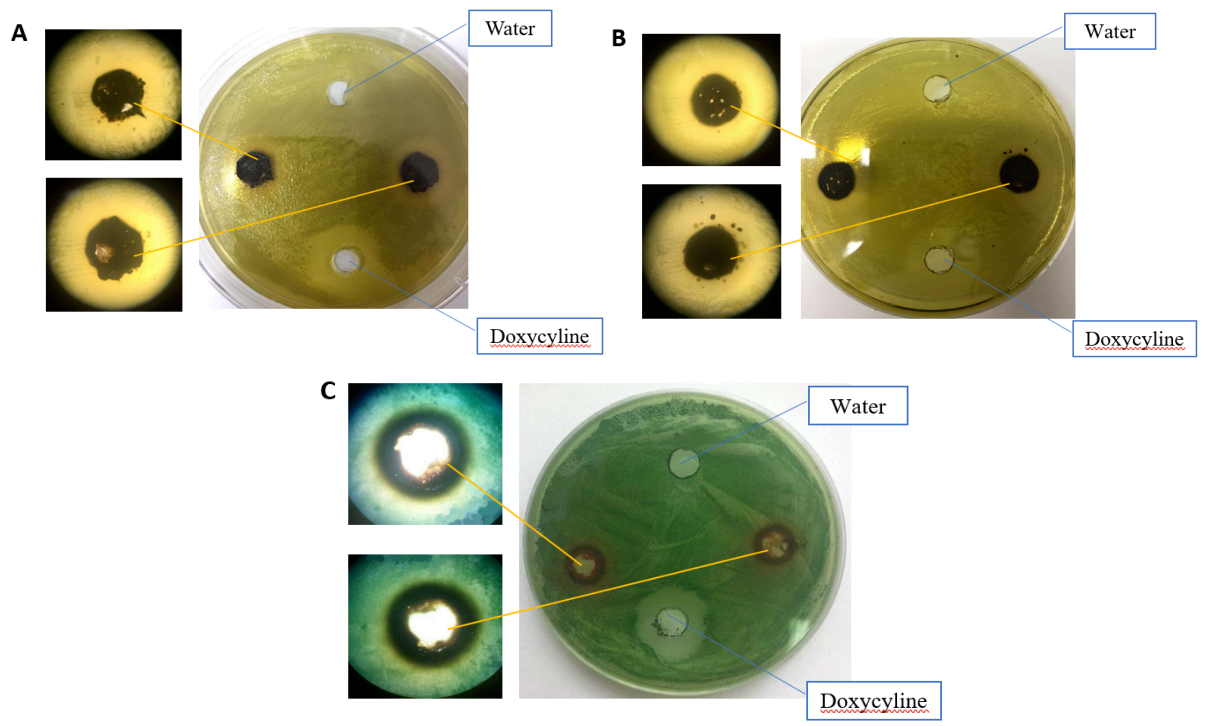

Figure 2. Agar well diffusion to check antibacterial activity result on representative plates for each type of tested sample. A - fresh feces; B - enriched feces; C - mucus. 
Testing antibacterial activity of tilapia fecal materials and mucus using agar well diffusion assay

Antibacterial activity of tilapia fecal materials and mucus testing using well diffusion method is shown in figure 2 . There were no completely clearing zone observed around wells containing the fecal or mucus materials. However, bacterial colonies adjacent to these wells were smaller than those further from the wells and they were in less number as well, thus creating the pseudo transparent rings around the wells containing either feces or mucus sample as shown in figure 2. These results show that fresh, enriched feces and mucus have a weak growth inhibition effect on $V$. parahaemolyticus.

\section{Factors in tilapia cultured water inhibit $V$. parahaemolyticus}

Water parameter including $\mathrm{pH}$, temperature, salinity in all cylinders used for the challenge tests were measured just before $V$. parahaemolyticus was added to make sure that environmental factors would not be the variable(s) that would influence the test outcome. Indeed, it was found that these parameters were of approximately equal among different treatment, $\mathrm{pH}$ and temperature was in range of optimized conditions for growth of $V$. parahaemolyticus ( $\mathrm{pH}: 7-8$, temperature: $24-30$ ). Therefore, the differences in $V$. parahaemolyticus density among treatments, if there were, were not accounted by these environmental factors.

Figure 3 shows the temporal changes in bacterial number in the four treatments. It can be seen that the number of bacteria at the initial time point (just after the addition of was $V$. parahaemolyticus into the cylinders or 0-hour post challenge) was approximately equal to $5 \times 10^{5} \mathrm{CFU} / \mathrm{ml}$ and insignificantly different between treatments Bacterial density in the SW treatment increased during the first three hours post challenge $(p<0.05)$, but then reduced to the level insignificantly different from the initial concentration at the 0 - hour time point $(p>$ 0.05) until the end of the experimental period Bacterial densities in the NF, NA and NAB treatments, which containing filter or non-filtered tilapia culture water (Table 1), at three-hours post challenge were all significantly lower $(p<0.05)$ than that of the negative SW treatment (approximately 17 times lower, Figure 3) Within each treatment, the bacterial densities in NF, NA and NAB at threehours post challenge significantly drop compared with the number of bacteria at the 0-hour time point $(\mathrm{p}<0.05)$ (Figure 3). From three to 24 hours, the total number of sucrose non-fermenting Vibrio spp. remained low and had no significant temporal change in these treatments (Figure 3). This result indicates that efficiency of $V$. parahaemolyticus inhibition activity of tilapia water is not different among the NF, NA and NAB treatments.

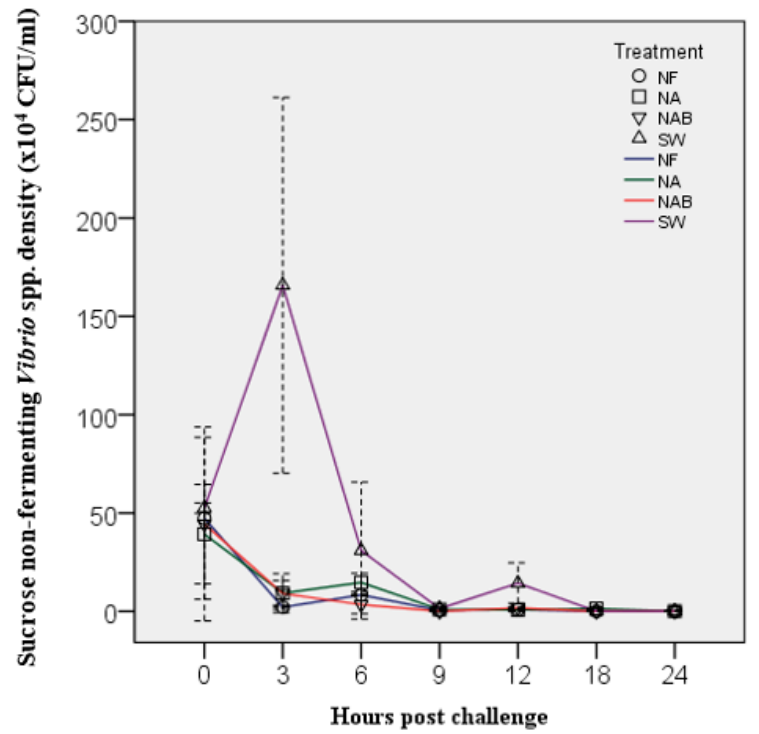

Figure 3. Temporal changes in total number of sucrose non-fermenting Vibrio spp. in bacterial challenge test with $V$. parahaemolyticus. Bacterial densities are expressed as mean $\pm \mathrm{SD}$ (CFU/ml). NF - non - filtered tilapia cultured water; NA tilapia cultured water removed algae; NAB - tilapia cultured water removed algae and bacteria; SW - sea water. 
The SW treatment showed higher bacterial concentration than the other treatments during the period between six to 24 hours. The differences were, however, not significant.

\section{DISCUSSION}

AHPND is a serious global disease, causing the loss of billions dollar to the shrimp production annually, and thus, is urgently required effective controlling methods. A deeper understanding of how co-culturing tilapia could lead to the reduction in damage caused by AHPND would help us actively plan strategies to control this disease.

Using agar well diffusion method to determine antibacterial activity of fecal material and mucus collected from tilapia showed that both materials could weakly inhibit the growth of $V$. parahaemolyticus, AHPND causing agent (Figure 2). This result is not in line with those of studies on antimicrobial effect of tilapia feces and mucus on the luminous bacteria $V$. harveyi. (Tendencia, dela Peña, 2003) reported that the tilapia (Tilapia hornorum) culture water, which were depleted of algae by culturing fish in the dark, well inhibited the growth of $V$. harveyi over a period of up to six days post challenge. It was proposed that bacteria of the gut flora of the fish, which are excreted into the water together with the feces, accounted for this repressive effect on luminous bacteria. In another study, the aqueous skin extracts of high saline and freshwater tilapia, Oreochromis mossambicus and Oreochromis sp. GIFT strain, could also inhibit the growth of $V$. harveyi (Caipang et al., 2011). In the study of Wibowo et al., (2015), tilapia mucus proteins were separated using Bradford method. These extracted proteins, with known concentration, were then used to test antibacterial effect against $V$. harveyi. In our study, mucus from tilapia skin and gill were scraped and directly used in the antimicrobial tests instead. The lack of strong antimicrobial activity of the mucus in our experiment may, therefore, due to the low concentration of potential antibacterial compounds existed in each well on the plate. The weak inhibition activity against $V$. parahaemolyticus of $O$. niloticus feces and mucus as demonstrated by the agar well diffusion method in our study suggests that they are not the main factors account for the observed AHPND controlling effect when shrimp was co-cultured with the tilapia.
On the contrary, results of the challenge tests strongly indicate that tilapia culture water contained component(s) that could efficiently inhibit the growth of $V$. parahaemolyticus (Figure 3 ). These results are consistent with previous study by Tran et al., (2014), who reported that water collected from the culturing of the tilapia $O$. niloticus could reduce shrimp mortality in the challenge test, in which Litopaneus vannamei was challenged with $3 \times 10^{5}$ cells/ml AHPND causing strain of $V$. parahaemolyticus. Tran et al. (2014), however, did not provide data showing the change of $V$. parahaemolyticus count at the end of the challenge test. In our experiment, the bacterial densities in treatments, in which filtered and non-filtered tilapia culture water were used (the NF, NA and NAB treatments), significantly reduced (at least four times reduction from 0 -hour time point) during the first three hours post challenge and significantly lower than those of the negative control, in which tilapia culture water was replaced by the sea water. From nine hours post challenge, bacterial count in each of these treatments then stayed as low as $4 \times 10^{3} \mathrm{CFU} / \mathrm{ml}$ until the end of the experiment (24 hours post challenge). It should be noted that $10^{4}$ $\mathrm{CFU} / \mathrm{ml}$ was considered as the threshold $V$. parahaemolyticus density, below which no shrimp mortality was observed in the study of SotoRodriguez et al., (2015).

Our result indicated that factor that directly influenced the growth of $V$. parahaemolyticus is not algae, which were filtered out of tilapia culture water used in NA treatment, and bacteria, which were not present in the water used in NAB treatment. Soluble compounds that could passed through the $0.22 \mu \mathrm{m}$ filter membrane, on the other hand, existed in water used for the NF, NA and NAB treatments, and thus, should be factor that exerted the direct inhibition activity against the growth of $V$. parahaemolyticus. Some previous studies from other authors support this finding. Makridis et al., (2006) suspected that superoxide produced by Chlorella and Tetraselmis, the two algae that often found the green water, may inhibit Vibrio growth. Moreover, some researchers showed that active substances from marine bacteria like Pseudomonas sp., Pseudoalteromonas sp. also have anti-Vibrio activity (Aranda et al., 2012; Rattanachuay et al., 2010). Therefore, further investigation into the characteristics and origins of these useful chemical compounds is necessary. 


\section{Conclusion and recommendation}

In conclusion, this study found that (1) tilapia fecal materials and mucus have very weak antibacterial activity; (2) soluble compounds smaller than $0.22 \mu \mathrm{m}$ in tilapia cultured water could directly and effectively inhibit the proliferation of $V$. parahaemolyticus. Their effect appeared rapidly, significant drop in $V$. parahaemolyticus density was readily observed in the first three hours post challenge.

Our finding would contribute to the development of effective strategies to protect the shrimp industry from the loss caused by AHPND. However, further studies are necessary to identify the nature and origin of antimicrobial compounds existing in tilapia cultured water. Assays like TLC, GCMS, FTIR will help us to narrow down the groups of bioactive compounds that have antimicrobial activity against $V$. parahaemolyticus. This information could serve as guidance for subsequent identification of the microorganisms that are the producers of these compounds.

Acknowledgement: This research is funded by International University - VNU-HCM under grant number: T2016-03-BT. The authors would like to thank the valuable support from all members in the team.

\section{REFERENCES}

Anderson JL, Valderrama D, Jory DE (2016) Global shrimp survey: GOAL 2016. Global aquaculture advocate. Retrieved https://www.aquaculturealliance.org/advocate/globalshrimp-survey-goal-2016.

Aranda CP, Valenzuela C, Barrientos J, Paredes J, Leal P, Maldonado M, Godoy FA, Osorio CG (2012) Bacteriostatic anti-Vibrio parahaemolyticus activity of Pseudoalteromonas sp. strains DIT09, DIT44 and DIT46 isolated from Southern Chilean intertidal Perumytilus purpuratus. World J Microbiol Biotechnol 28(6): 23652374. doi:10.1007/s11274-012-1044-z.

Caipang CMA, Avenido P, Dechavez R, Jaspe CJ (2011) Moderate inhibition of luminous Vibrio harveyi by aqueous extracts obtained from the skin of tilapia, Oreochromis sp. Philipp J Sci 140(2): 173-178.

Cruz PS, Andalecio MN, Bolivar RB, Fitzsimmons KM (2008) Tilapia-Shrimp Polyculture in Negros Island, Philippines: A Review. J World Aquac Soc 39(6): 713725. doi:10.1111/j.1749-7345.2008.00207.x

FAO (2013) Report of the FAO/MARD technical workshop on early mortality syndrome (EMS) or acute hepatopancreatic necrosis syndrome (AHPNS) of cultured shrimp (under TCP/VIE/3304). FAO Fisheries and Aquaculture Report No. 1053. FAO, Hanoi, Viet Nam.

Hernández-Barraza C, Loredo J, Adame J, Fitzsimmons KM (2012) Effect of Nile tilapia (Oreochromis niloticus) on the growth performance of Pacific white shrimp (Litopenaeus vannamei) in a sequential polyculture system. Lat Am $J$ Aquat Res 40: 936-942. doi:10.3856/vol40-issue4-fulltext-10.

Ho HC (2016) Potential role of the tilapia, Oreochromis niloticus, in controlling of acute hepatopancreatic necrosis disease (AHPND) (bachelor dissertation) International University, VNU-HCM. Ho Chi Minh City, Vietnam.

Leaño EM, Lio-Po GD, Nadong LA, Tirado AC, Sadaba RB, Guanzon NG (2005) Mycoflora of the 'green water' culture system of tiger shrimp Penaeus monodon Fabricius. Aquac Res 36(16): 1581-1587. doi:10.1111/j.1365-2109.2005.01381.x.

Lee CT, Chen IT, Yang YT, Ko TP, Huang YT, Huang JY, Huang MF, Lin SJ, Chen CY, Lin SS, Lightner DV, Wang HC, Wang AH, Wang HC, Hor LI, Lo CF (2015) The opportunistic marine pathogen Vibrio parahaemolyticus becomes virulent by acquiring a plasmid that expresses a deadly toxin. Proc Natl Acad Sci U S A 112(34): 10798-10803. doi:10.1073/pnas.1503129112.

Lio-Po GD, Leaño EM, Peñaranda MMD, Villa-Franco AU, Sombito CD, Guanzon NG (2005) Anti-luminous Vibrio factors associated with the 'green water' grow-out culture of the tiger shrimp Penaeus monodon. Aquaculture 250(1): 1-7. doi:10.1016/j.aquaculture.2005.01.029.

Makridis P, Costa RA, Dinis MT (2006) Microbial conditions and antimicrobial activity in cultures of two microalgae species, Tetraselmis chuii and Chlorella minutissima, and effect on bacterial load of enriched Artemia metanauplii. Aquaculture 255(1): 76-81. doi:10.1016/j.aquaculture.2005.12.010.

Rattanachuay P, Kantachote D, Tantirungkij M, Nitoda T, Kanzaki H (2010) Inhibition of shrimp pathogenic vibrios by extracellular compounds from a proteolytic bacterium Pseudomonas sp. W3. Electron J Biotechnol 13(1). doi:10.2225/vol13-issue1-fulltext-2.

Soto-Rodriguez SA, Gomez-Gil B, Lozano-Olvera R, Betancourt-Lozano M, Morales-Covarrubias MS (2015) Field and experimental evidence of Vibrio parahaemolyticus as the causative agent of acute hepatopancreatic necrosis disease of cultured shrimp (Litopenaeus vannamei) in Northwestern Mexico. Appl Environ Microbiol 81(5): 1689-1699. doi:10.1128/AEM.03610-14.

Tendencia EA, dela Peña MR (2003) Investigation of some components of the greenwater system which makes it effective in the initial control of luminous bacteria. Aquaculture 218(1): 115-119. doi:10.1016/S00448486(02)00524-0. 
Tendencia EA, dela Peña MR, Fermin AC, Lio-Po GD, Choresca CH, Inui Y (2004) Antibacterial activity of tilapia Tilapia hornorum against Vibrio harveyi. Aquaculture 232(1): 145-152. doi:10.1016/S00448486(03)00531-3.

Tran L, Fitzimmons KM, Lightner DV (2014) Tilapia could enhance water conditions, help control EMS in shrimp ponds. Global Aquaculture Advocate 2014(January/February): 11-12.

Tran L, Nunan L, Redman RM, Mohney LL, Pantoja CR, Fitzsimmons KM, Lightner DV (2013) Determination of the infectious nature of the agent of acute hepatopancreatic necrosis syndrome affecting penaeid shrimp. Dis Aquat Organ 105(1): 45-55. doi:10.3354/dao02621.
Wibowo A, Fadjar M, Maftuch (2015) Utilization of tilapia mucus to inhibit Vibrio harveyi on Vannamei (Litopenaeus vannamei). J Life Sci Biomed 5(5): 141-148.

Yi Y, Fitzsimmons KM (2004) Tilapia-shrimp polyculture in Thailand. In Fitzsimmons KM, Bolivar RB, Mair G, eds. ISTA - 6th International Symposium on Tilapia in Aquaculture Proceedings. BIOTECH.

Yuan D, Yi Y, Yakupitiyage A, Fitzimmons KM, Diana JS (2010) Effects of addition of red tilapia (Oreochromis spp.) at different densities and sizes on production, water quality and nutrient recovery of intensive culture of white shrimp (Litopenaeus vannamei) in cement tanks. Aquaculture 298(3): 226-238. doi:10.1016/j.aquaculture.2009.11.011.

\section{KHẢ NĂNG ỬC CHẾ VI KHUẨ GÂY BÊNH HOẠI TỦ GAN TỤY CẤP (AHPND) - VIBRIO PARAHAEMOLYTICUS - CỦA PHẦN, CHẤT NHẦY VÀ NƯớC NUÔI CÁ RÔ PHI - OREOCHROMIS NILOTICUS}

\section{Lê Ngọc Phương Thanh, Hồ Hải Co, Trịnh Thị Trúc Ly, Hoàng Tùng, Bùi Thị Hồng Hạnh}

Đại học Quốc tế, Đại học Quốc gia Thành phố Hồ Chi Minh

\section{TÓM TẮT}

Nuôi tôm đóng vai quan trọng trong nền kinh tế của nhiều nước trên thế giới. Nhưng trong những năm gần đây, bệnh hoại tử gan tụy cấp (AHPND), còn được biết đến như "Hội chứng chết sớm ở tôm" (EMS), đã gây thiệt hại lên đến hàng tỷ đô la cho nghề nuôi tôm ở các quốc gia khu vực châu Á và Trung Mỹ. Cho đến nay, chưa có giải pháp hữu hiệu để ngăn ngừa và điều trị AHPND. Tuy nhiên, nhiều trang trại nuôi tôm ở một số nước đã ghi nhận nuôi ghép tôm và cá rô phi có thể hạn chế sự xuất hiện và bùng phát của AHPND. Mục tiêu của nghiên cứu này là xác định các yếu tố nội sinh của cá rô phi hoặc nước nuôi cá có khả năng gây ức chế sự phát triển của Vibrio parahaemolyticus - tác nhân gây AHPND. Các yếu tố được khảo sát bao gồm: chất nhầy trên da cá, mang cá, phân cá, và các thành phần vi sinh hoặc chất hoà tan trong nước nuôi cá. Khả năng ức chế $V$. parahaemolyticus của phân cá lấy trực tiếp hoặc ủ qua đêm và chất nhầy trên da và mang cá được kiểm tra bằng phương pháp khuếch tán qua giếng thạch. Cả hai loại phân cá và chất nhầy đều cho kết quả ức chế yếu. Thử nghiệm sàng lọc tác nhân ức chế $V$. parahaemolyticus trong nước nuôi cá bằng phương pháp cảm nhiễm cho thấy các hợp chất hòa tan có kích thước nhỏ hơn $0.22 \mu \mathrm{m}$ có khả năng ức chế sự phát triển của $V$. parahaemoliticuscao gấp 17 lần so với nghiệm thức đối chứng âm trong khoảng ba giờ đầu tiên sau cảm nhiễm.

Từ khóa: $A H P N D$, chất nhầy trên da và mang cá rô phi, EMS, nước nuôi cá rô phi, phân cá rô phi, tôm, Vibrio parahaemolyticus 